\title{
A RELATÍV FOGYASZTÁS A VISELKEDÉSI KÖZGAZDASÁGTAN PERSPEKTÍVÁJÁBAN
}

\section{RELATIVE CONSUMPTION IN A BEHAVIOURAL ECONOMIC PERSPECTIVE}

\author{
Kovács Kármen \\ PhD, dr. habil., egyetemi docens, Pécsi Tudományegyetem Közgazdaságtudományi Kar \\ kovacs.karmen@ktk.pte.hu
}

\begin{abstract}
ÖSSZEFOGLALÁS
A tanulmány célja, hogy rámutasson a relatív fogyasztás szerepére, megnyilvánulására és következményeire - elsősorban az egyén szempontjából - a viselkedési közgazdaságtan szemléletmódja alapján. Amíg a neoklasszikus közgazdaságtan szerint az egyén fogyasztói hasznossága csak a saját fogyasztásának abszolút szintjétől függ, a viselkedési közgazdaságtan azt is számításba veszi, mennyit fogyaszt az egyén másokhoz viszonyítva. Így a relatív fogyasztás is hatást gyakorol az egyén realizált hasznosságára. A társas összehasonlítás, az egyén saját fogyasztásának másokéval való összevetése többféleképpen is megvalósulhat. Kvantitatív szempontból különbség, arány vagy rangsor alapján. A referenciacsoportot alkothatja a társadalom egésze, de valószerűbb, hogy a szűkebb társas környezetében lévő egyének. Az egyén viszonyíthat a referenciacsoportjába tartozó egyének fogyasztásának átlagához, de az egyénenkénti összehasonlítás érvényessége sokkal inkább igazolt. A relatív fogyasztást dinamikus szemléletben tanulmányozzuk. Egyfelöl, mert az egyének közötti folyamatos versengésben nyilvánul meg. Másfelől, mások jelenbeli és múltbeli fogyasztása egyaránt befolyásolja az egyén jelenbeli fogyasztói hasznosságát. Ha az egyén szeretné javítani vagy megőrizni pozícióját a jövőben, akkor a referenciacsoportjába tartozó egyének jövőbeni fogyasztását is szükséges megbecsülnie. Jövőre vonatkozó várakozásai azonban nem feltétlenül igazolódnak - döntésének kimenetele bizonytalan, és ez a relatív pozíciójának csökkenését eredményezheti. Az egyén pozicionális javakba való fektetése során pénzügyi helyzetét is figyelembe veszi; nem lehet azonban biztos a megtérülésben, a nagyobb fogyasztói hasznosság elérésében. A pozícióért való rivalizálás következménye túlköltekezés és a megtakarítási szint csökkenése lehet - a relatív pozició javulása nélkül. Az egyén a relatív fogyasztás negatív hatásait a benső motivációira való nagyobb odafigyeléssel és a jövedelme tudatosabb allokálásával mérsékelheti.
\end{abstract}

\section{ABSTRACT}

The purpose of this paper is to point out the role, manifestation and consequences of relative consumption from the perspective of behavioural economics. According to neoclassical economics, an individual's consumer utility depends only on his own absolute consumption level; however, behavioural economics also takes into account how much an individual consumes 
compared to others. Thus, relative consumption also has an impact on an individual's realised utility. Social comparison, the comparison of an individual's own consumption with others, can take place in several ways; quantitatively, based on difference, ratio, or ranking. The reference group can consist of the society as a whole, but more realistic to see individuals in his immediate social environment. The individual can compare to the average consumption of individuals in his reference group, but the validity of the individual comparison is more justified. Relative consumption is studied dynamically. On the one hand, it is manifested in the continuous rivalry among individuals. On the other hand, the current and past consumption of others affects the individual's current consumer utility. If an individual wants to improve or preserve his position in the future, then it is necessary to estimate the future consumption of the individuals in his reference group. However, his expectations for the future are not necessarily justified, the outcome of his decision is uncertain, and this may lead to a reduction in his relative position. An individual also takes his financial position into account when he invests in positional goods; however, he cannot be sure of the return on investment to achieve a higher consumer utility. Rivalry for the social position may result in overspending and a reduction in savings, without improving relative position. An individual can mitigate the harmful effects of relative consumption by paying more attention to his inner motivations and by more consciously allocating his income.

Kulcsszavak: relatív fogyasztás, referenciapont, társadalmi státusz, versengés, társas összehasonlítás

Keywords: relative consumption, reference point, social status, rivalry, social comparison

\section{BEVEZETÉS}

A neoklasszikus közgazdaságtantól eltérően a viselkedési közgazdaságtan szerint az egyén fogyasztásból származó hasznossága nemcsak saját fogyasztásának abszolút szintjétől függ, hanem attól is, mennyit fogyaszt másokhoz viszonyítva - ez a relatív fogyasztás. Következésképpen, az egyén nemcsak arra vagy nem feltétlenül arra törekszik, hogy az általa élvezett hasznosságot növekvő fogyasztási szinttel fokozza, hanem hogy másokhoz képest nagyobb, kedvezőbb fogyasztást érjen el.

Sarah J. Solnick és David Hemenway (1998) arra mutatnak rá sokat idézett cikkükben, hogy az emberek többsége számára fontosabb a másokhoz viszonyított nagyobb fogyasztás, vagyis a relatív fogyasztás, mint a magasabb abszolút fogyasztási szint. Felmérésük során arra kérték a válaszadókat, hogy döntsék el két lehetséges állam közül, melyikben szeretnének élni. Abban, amelyben erőforrásaik (például jövedelem) abszolút szintje magas, másokhoz viszonyítva azonban ezekből kevesebbet birtokolnak - ezt nevezik abszolút államnak. Vagy egy olyan államban, ahol az erőforrásaik abszolút mennyisége alacsonyabb, de másokhoz képest mégis többel rendelkeznek - ez a pozicionális állam. A megkérdezettek 
többsége a pozicionális államot választotta, annak ellenére, hogy a tradicionális közgazdaságtan felfogása szerint az egyének az abszolút államot preferálják. Egy példával illusztrálva ez azt jelenti, hogy ha az egyén autójának értéke $5 \mathrm{M} \mathrm{Ft}$, míg másoké $3 \mathrm{M} \mathrm{Ft}$, akkor ezt a helyzetet elönyben részesíti azzal szemben, ha autója 7 M Ft-ot érne, másoké viszont 10 M Ft-t. Solnick és Hemenway (1998) felmérését több országban és különböző kontextusokban is megismételték, azonos eredménnyel.

Szakirodalmi vita van a különböző javak relatív fogyasztásban és társadalmi státuszért való versengésben betöltött jelentőségéről. Korábban határozottan elkülönítették a rivalizálás során fontos javakat; Fred Hirsch (1976) ezeket pozicionális javaknak nevezte, például a ház, az autó és az ékszerek tartoznak ide. A tömegkommunikáció szerepének erősödésével, a fogyasztói társadalom kialakulásával, valamint a közösségi média elterjedésével azonban jelentősen kibővült azon javak köre, amelyek mások számára megfigyelhetők, és szerepet játszanak a másokkal való összehasonlításban - csoportjuk nem határolható le egyértelmüen.

A relatív fogyasztás mindenkit érint. Az egyénnel kapcsolatban álló személyek fogyasztása befolyásolja az egyén relatív pozícióját. Továbbá, nem feltétlenül tudatos a mások fogyasztásához való viszonyulás és a versengés. Így az egyének sokszor nincsenek tudatában a rivalizálás mögötti tényezőknek és következményeinek. Jellemző a fogyasztási döntésekhez kötődő bizonytalanság alulbecslése és a pozicionális javakra való túlköltekezés - utóbbi a pénzügyi források tudatosabb allokálásával megelőzhető lenne. A tanulmány mindennek megértésében segítheti a nem közgazdász olvasókat is, a társas összehasonlításra és a személyes pénzügyek relációira koncentrálva.

\section{A TÁRSAS ÖSSZEHASONLITTÁS A RELATÍV FOGYASZTÁS SORÁN}

A relatív fogyasztás növelésének és a társadalmi pozíció javításának aspirációja a társadalom minden rétegében jelen van, azonban más-más formában nyilvánul meg az eltérő vagyoni és jövedelmi szintből, értékrendből és életstílusból adódóan. Az azonban általánosságban jellemző, hogy a relatív fogyasztás erősítését célzó törekvések mögött érzelmek húzódnak meg, az irigység a meghatározó (Solnick-Hemenway, 1998).

A relatív fogyasztás a Leon Festinger (1954) nevéhez füződő társas összehasonlítás elmélete alapján is magyarázható, amelynek alapfeltételezése, hogy az egyének pontosan szeretnék önmagukat értékelni, ezért összemérik magukat másokkal. Az összehasonlítást különösen bizonytalan helyzetekben igénylik, amikor önértékelésük számukra fontosabbá, referenciapont segítségével pedig megragadhatóbbá válik. Ed Hopkins és Tatiana Kornienko (2009) szerint a relatív fogyasztásukat fokozni szándékozó egyének számára a körülöttük lévő szemé- 
lyek a legfontosabbak referenciapontokként; a társas összehasonlítás és a rivalizálás elsődlegesen velük valósul meg.

Kvantitatív aspektusból tekintve, az egyén saját fogyasztását többféle módon is összevetheti másokéval. Történhet különbség és arány alapján - ez a státusz kardinális értelmezéséhez kötődik. A rangsoralapú összehasonlítás viszont az ordinális aspektusú státuszt fejezi ki, amely a státuszt közvetítő javak birtoklásának eloszlásában lévő társadalmi pozíciót tükrözi (Bilancini-Boncinelli, 2008). Az egyént valójában nem az objektív státusza befolyásolja, hanem az általa észlelt relatív pozíciója, amely az ő szubjektív benyomásán alapul. Ennio Bilancini és Leonardo Boncinelli (2008) kiemelik, hogy nem indifferens, a státusz melyik értelmezési módját alkalmazzák a kutatások során, mert eltérő eredmények és következtetések adódhatnak.

Nincs konszenzus a kutatók között arról, kik alkotják az egyén referenciacsoportját a relatív fogyasztás során. A konzervatívabb és kevésbé valószerü nézet szerint az egyén a társadalom összes tagjához viszonyítja fogyasztását. Ezzel szemben a valósághübb szemléletmódot képviselők, így Hopkins és Kornienko (2009) is úgy érvelnek, hogy a referenciacsoport tagjait az egyén szükebb társas környezetében lévő egyének alkotják. Mark D. Alicke (2007) ezt azzal magyarázza, hogy a mindennapi életben az egyén társas interakciói a hozzá közel álló kis csoportok (például munkaközösség) tagjaival zajlanak. Vita tárgyát képezi az is, hogy az egyén egyénenként hasonlítja össze fogyasztását másokéval, avagy a referenciacsoportjába tartozó egyének fogyasztásának átlagához méri a sajátját. Alicke (2007) szerint utóbbinak csak akkor van relevanciája, ha normák vagy tipikus jellemzők képezik az összevetés alapját. Az egyénenkénti összehasonlitás érvényességét hangsúlyozza, amely összhangban áll Festinger (1954) társas öszszehasonlítás elméletével; az egyén a relatíve szük társas környezetének tagjaival képes összevetni magát, és ez bizonyítottan jelentős hatást gyakorol az önértékelésére (Alicke, 2007).

A szakirodalomban sokáig csak egy referenciaponttal dolgoztak a kutatók, ez a valóságot azonban jelentősen leegyszerüsíti. Egyidejüleg rendszerint több referenciapont befolyásolja az egyén döntéshozatalát, ez érvényes a relatív fogyasztás során is. A több referenciapont hatásának nagy jelentősége van bizonytalan és kockázatos, valamint intertemporális döntési helyzetekben. Mindegyik jellemzi a relatív fogyasztást.

Danirl Kahneman (1992) megállapítja, hogy több referenciapont esetében az egyén összehasonlíthatja döntésének eredményét minden egyes referenciaponttal külön-külön, de egyetlen referenciaponttá is integrálhatja azokat, átfogó értékelést megvalósítva. Lisa D. Ordóñez és szerzőtársai (2000) eredményei szerint az egyén külön kezeli az egyes referenciapontokat. Ez összhangban áll Festinger (1954) teóriájával és Alicke (2007) azon megállapításával is, hogy egyénenkénti összehasonlítás történik. Ordóñez és szerzőtársai (2000) szerint a szegregáció a 
referenciapontok összevethetőségének hiánya vagy nehézsége miatt valósul meg, integráció pedig akkor valószínűbb, amikor a referenciapontok könnyen összemérhetők. A különböző referenciapontoknak konvergens és divergens hatása is lehet a magatartásra; ezt empirikus vizsgálatok is megerősítik.

Az egyének közti versengés folyamatos a fejlett társadalmakban, ezért a relatív fogyasztást is dinamikus szemléletben célszerü vizsgálni. Thomas Aronsson és Olof Johansson-Stenman (2014) három tényezőt különböztet meg, amelyek befolyásolják és módosítják a fogyasztást az idő előrehaladtával: a (belső) szokások kialakulása, a „másokkal való lépéstartás” és a „mások utolérése” (külső szokások kialakulása). ${ }^{1}$ Ez úgy is megfogalmazható, hogy az egyén jelenbeli fogyasztására és az abból eredő hasznosságára az egyén saját múltbeli fogyasztása, mások múltbeli fogyasztása és mások jelenbeli fogyasztása van hatással; ez három meghatározó referenciapontot jelent a relatív fogyasztás esetében. Az emberek általában törekszenek társadalmi pozíciójuk javítására, így referenciapontként szolgálhatnak számukra a maguknál előnyösebb státuszúnak tekintett egyének.

A fentiekben említett referenciapontok múltbeliek vagy jelenbeliek. Köszegi Botond és Matthew Rabin (2009) alapján a várakozások is releváns referenciapontok lehetnek. A jövőre vonatkoznak, és bizonytalanságot foglalnak magukban, mert a jövőbeni körülmények nem feltétlenül az egyén várakozásai szerint alakulnak. Ha az egyén várakozásai alapján hoz döntést, vagyis a döntése jövőbeni kimenetele bizonytalan, csalódás és siker egyaránt érheti. Mindez releváns a relatív fogyasztás esetében, mivel ha az egyén szeretné javítani vagy legalább megőrizni pozícióját a jövőben, akkor a referenciacsoportjába tartozó egyének jövőbeni fogyasztását is szükséges mérlegelnie, azt megbecsülnie.

Mivel az egyének fogyasztási döntése egymástól függő, a várható és a realizált fogyasztói hasznosságot egyaránt befolyásolják a társas referenciapontok. Hopkins és Kornienko (2004) kiemelik, hogy az egyén csak akkor tud optimális fogyasztást megvalósítani, ha mások fogyasztási döntését pontosan előre tudja jelezni. Következésképpen, a mások jövőbeni fogyasztásával és annak hatásaival kapcsolatos várakozásoknak, amelyek beépülnek az egyén - bizonytalan jövőbeni kimenetelü - döntésébe, kritikus szerepük van az egyén relatív pozíciójának és az általa realizált fogyasztói hasznosságszint változásában.

Ha az egyén relatív fogyasztásának növelésével kívánja a jövőbeni fogyasztói hasznosságát javítani, akkor mások jövőbeni abszolút fogyasztásának becslése és

${ }^{1}$ A „,másokkal való lépéstartás” kifejezést a „keeping up with the Joneses” megfelelöjeként használom. Azt fejezi ki, hogy az egyén fogyasztói hasznosságát befolyásolja, miként viszonyul jelenlegi fogyasztása mások jelenlegi fogyasztásához. A „catching up with the Joneses” jelentése „mások utolérése”, vagyis az egyén jelenlegi fogyasztói hasznossága függ attól, hogyan viszonyul az egyén jelenlegi fogyasztása mások korábbi fogyasztásához. 
az összevetés során a nekik tulajdonított fontosság alapján meghatározott súlyok figyelembevételével határozza meg abszolút fogyasztását. Amennyiben az egyén úgy dönt, hogy fokozza abszolút fogyasztását, nem feltétlenül valósul meg relatív fogyasztásának és fogyasztói hasznosságának növekedése. Lehetséges, hogy alábecsüli mások abszolút fogyasztását, vagyis várakozásai nem igazolódnak, és ez relatív pozíciójának csökkenését eredményezi. Ekkor a realizált fogyasztói hasznosság a vártnál alacsonyabb lesz, akár olyannyira, hogy a döntés időpontjában lévő realizált hasznosságot sem éri el - ez azt jelenti, hogy az egyén kedvezőtlenebb pozícióba kerül a döntés időpontjában érvényeshez képest. Ez csalódást jelent számára, és az énképére negatív hatást gyakorolhat. Különösen akkor, ha viszonylag drága jószágba fektetett, illetve megtakarításait és/vagy hitelfelvételt felhasználva kísérelte meg relatív pozíciójának javítását.

\section{A RELATÍV FOGYASZTÁS SZEMÉLYES PÉNZÜGYEKET ÉRINTŌ VONATKOZÁSAI}

Az emberek általában pénzügyi helyzetük romlása nélkül kívánják relatív fogyasztásukat javítani. A társas referenciapontok mellett tehát az egyén számára releváns a pénzügyi helyzete is, amely pénzügyi referenciapontként van jelen a döntése során. Jingyi Lu és szerzőtársai (2015) amellett érvelnek, hogy az egyén elsőként a pénzügyi referenciapontjait mérlegeli, aztán fontolja meg a társas referenciapontjait. Ennek oka, hogy az emberek akkor érzik magukat biztonságban, ha meg tudják valósítani pénzügyi terveiket. Így a relatív fogyasztásból származó hasznosságot a társas és a pénzügyi referenciapontok egyaránt befolyásolják. Hirsch (1976) megállapítja, hogy ha az egyén jövedelme növekszik, akkor jövedelmének egyre nagyobb hányadát költi pozicionális javakra. Annak ellenére, hogy a fogyasztás marginális hasznossága csökken, az egyén mégis motivált a fogyasztásának növelésében, mert nagyobb fogyasztás szükséges a magasabb társadalmi pozíció eléréséhez.

Az egyén pozicionális javakba történő befektetésekor mérlegeli pénzügyi helyzetét, társadalmi pozíciójának és fogyasztói hasznosság szintjének növelésére vonatkozó vágyódását, valamint saját és mások döntésének hatásával kapcsolatos várakozásait. A befektetésének megtérülése bizonytalan, így a magasabb státusz és a nagyobb fogyasztói hasznosság elérése is. Ha az egyén nem veszi figyelembe vagy alábecsüli döntésének bizonytalanságát, különösen a pénzügyi helyzetéhez viszonyítva, akkor a viszonylag magas árú, tartós pozicionális javak (például autó) megvásárlásával akár tartósan is gyengítheti relatív pozícióját, különösen akkor, ha azt hitelfelvétellel finanszírozza.

Játékelméleti megközelítéssel is vizsgálhatók a fogyasztási kiadások különböző faktorokkal való relációi. Hopkins és Kornienko (2009) arra mutatnak rá, hogy a pozícióért való rivalizálásnak mint játéknak a Nash-egyensúlya nem 
hatékony abban az értelemben, hogy minden játékos, vagyis fogyasztó, az optimálisnál többet költ pozicionális javakra, a túlköltekezés azonban mégsem eredményezi a relatív pozíció javulását. Kiemelik továbbá, hogy a társadalomra jellemző nagyobb mértékủ egyenlőség fokozza a pozicionális javakra való ráfordítások mértékét. Ennek oka, hogy az ilyen típusú javakkal rendelkező egyének könnyebben javíthatják társadalmi pozíciójukat a kedvezőbb relatív fogyasztásukból eredően.

A státuszért való véget nem érő rivalizálás Robert H. Frank (2007) szerint társadalmi szinten a pozicionális javakra való költekezés versengéséhez vezet, amely - a fogyasztási externáliákból eredően - minden fogyasztóra negatívan hat, forrásaik kimerülését eredményezheti. Ebböl az aspektusból pazarló költekezés történik. Frank (2007) - a fentiekkel összhangban - megállapítja, hogy a pozicionális törekvéseket tartalmazó modellek olyan egyensúlyt anticipálnak, amelyben az egyének a pozicionális javakra túl sokat költenek, ugyanakkor a normál javakra relatíve keveset.

Érdemes azzal is foglalkozni, miként befolyásolja a relatív fogyasztás erősítését célzó magatartás az egyén megtakaritásait. Ez nemcsak azért releváns, mert a versengés folyamatos, és az egyének döntései intertemporális jellegüek, hanem azért is, mert több olyan, a funkcionális hasznossága mellett státuszt is tükröző tartós jószág létezik, amely ára relatíve magas, következésképpen megvásárlásukhoz megtakarítás és/vagy hitelfelvétel szükséges, valamint mert az egyén jószágkosarában jelentős hányadot képvisel azon javak csoportja, amelyek birtokosuk pozícióját valamilyen formában és mértékben közvetítik.

Eltérőek az empirikus vizsgálatok eredményei azzal kapcsolatban, miként befolyásolja az egyén megtakarítását a pozicionális javak vásárlása; az optimálisnál alacsonyabb és magasabb megtakarítási szintre is vannak példák. James S. Duesenberry (1949) rámutatott arra, hogy a „másokkal való lépéstartásra” törekvő egyén növeli jelenbeli fogyasztását, azonban a magasabb fogyasztási kiadás alacsonyabb megtakarítási szintet eredményez. Következésképpen, a jövőben csak alacsonyabb fogyasztási szintet tud finanszírozni, amely a relatív pozíciójának gyengülését eredményezheti. Ekkor tehát az egyén nem veszi figyelembe vagy alábecsüli jelenbeli fogyasztási döntése következményeit. Moritz Drechsel-Grau és Kai Daniel Schmid (2014) a felfelé történő összehasonlítást vizsgálja, amikor az egyén referenciacsoportját önmagánál vagyonosabbnak észlelt egyének alkotják. Eredményeik szerint az egyén megtakarításai kárára növeli fogyasztási kiadásait, ha azt figyeli meg, hogy a nála tehetősebbek fokozzák a fogyasztásukat. A relatív fogyasztás fokozására törekvő magatartás azonban nem feltétlenül eredményezi a megtakarítás csökkenését. Richmond Harbaugh (1996) megállapítja, hogy az előretekintő és kockázatkerülő egyén a társadalmi státuszért való versengés során odafigyel a jelenbeli megtakarítására annak érdekében, hogy megelőzze a pozíciójában való jövőbeni gyengülést. 


\section{KÖVETKEZTETÉSEK}

A társadalom minden tagját érintő relatív fogyasztás az egyén fogyasztói hasznosságát és pénzügyi helyzetét egyaránt befolyásolja. A fogyasztási döntések kimenetele bizonytalan az egyének egymástól függéséből eredően, a túlköltekezés ellenére akár a relatív pozíció gyengülésével is járhat. A benső motivációira való nagyobb odafigyeléssel és a jövedelme tudatosabb allokálásával azonban mérsékelhetők negatív következményei. A pazarló kiadások megfékezésére Frank (2007) a gazdaságpolitikai döntéshozóknak a progresszív fogyasztási adót javasolja, amely minden jövedelemszint mellett nagyobb jólétet eredményezne, egyúttal ösztönözné a megtakarítást, és csökkentené a környezeti ártalmakat. Már Thorstein Veblen $(1899,1979)$ rámutatott a versengéshez kötődő fogyasztás ökológiailag káros hatására a pazarló kiadásokon keresztül: a fogyasztók értékesebb vagy több jószágot vásárolnak a számukra valóban szükségesnél, amelyet a vállalatok a szükös erőforrások nem hatékony felhasználásával állítanak elö.

A publikáció a Bolyai János Kutatási Ösztöndij támogatásával készült.

\section{IRODALOM}

Alicke, M. D. (2007): In Defense of Social Comparison. Revue Internationale de Psychologie Sociale, 20, 1, 11-29. https://www.cairn.info/revue-internationale-de-psychologie-sociale-2007-1-page-11.htm

Aronsson, T. - Johansson-Stenman, O. (2014): Positional Preferences in Time and Space: Optimal Income Taxation with Dynamic Social Comparisons. Journal of Economic Behavior \& Organization, 101, 1-23. DOI: 10.1016/j.jebo.2014.01.004, https://www.researchgate.net/publication/260110739_Positional_Preferences_in_Time_and_Space_Optimal_Income_Taxation_ with_Dynamic_Social_Comparisons

Bilancini, E. - Boncinelli, L. (2008): Ordinal vs Cardinal Status: Two Examples. Economics Letters, 101, 1, 17-19. DOI: 10.1016/j.econlet.2008.03.027

Drechsel-Grau, M. - Schmid, K. D. (2014): Consumption-savings Decisions under Upward-looking Comparisons. Journal of Economic Behavior \& Organization, 106, C, 254-268. DOI: 10.1016/j. jebo.2014.07.006, https://www.researchgate.net/publication/264161591_Consumption-Savings_ Decisions_Under_Upward-Looking_Comparisons

Duesenberry, J. S. (1949): Income, Saving and the Theory of Consumer Behavior. Cambridge, MA: Harvard University Press, https://archive.org/details/in.ernet.dli.2015.84155/page/n7

Festinger,L.(1954): A Theory of Social Comparison Processes. Human Relations, 7, 2, 117-140. DOI: 10.1177/001872675400700202, https://pdfs.semanticscholar.org/6de4/e806365af08e3445eb374 fee96df74e08384.pdf

Frank, R. H. (2007): Falling Behind: How Rising Inequality Harms the Middle Class. Berkeley: University of California Press

Harbaugh, H. R. (1996): Falling Behind the Joneses: Relative Consumption and the Growth-Savings Paradox. Economics Letters, 53, 297-304. DOI: 10.1016/s0165-1765(96)00933-0, https:// kelley.iu.edu/riharbau/joneses.pdf 
Hirsch, F. (1976): Social Limits to Growth. Cambridge, MA: Harvard University Press, https:// archive.org/details/sociallimitstogr00fred

Hopkins, E. - Kornienko, T. (2004): Running to Keep in the Same Place: Consumer Choice as a Game of Status. American Economic Review, 94, 4, 1085-1107. DOI: 10.1257/0002828042002705, https://pdfs.semanticscholar.org/3a63/7d2e3a38909eaf01533b9a99aa307b3c9069.pdf

Hopkins, E. - Kornienko, T. (2009): Status, Affluence, and Inequality: Rank-based Comparisons in Games of Status. Games and Economic Behavior, 67, 2, 552-558. DOI: 10.1016/j.geb. 2009.02.004, http://homepages.econ.ed.ac.uk/ tatiana/papers/hopkins-kornienko-geb2009.pdf

Kahneman, D. (1992): Reference Points, Anchors, Norms, and Mixed Feelings. Organizational Behavior and Human Decision Processes, 51, 2, 296-312. DOI: 10.1016/0749-5978(92)90015-y

Köszegi B. - Rabin, M. (2009): Reference-dependent Consumption Plans. American Economic Review, 99, 3, 909-936. DOI: 10.1257/aer.99.3.909, http://www.personal.ceu.hu/staff/Botond Koszegi/drp.pdf

Lu, J. - Xie, X. - Wang, M. - Tang, X. (2015): Double Reference Points: The Effects of Social and Financial Reference Points on Decisions under Risk. Journal of Behavioral Decision Making, 28, 5, 451-463. DOI: 10.1002/bdm.1862, https://www.researchgate.net/publication/273159705_ Double_Reference_Points_The_Effects_of_Social_and_Financial_Reference_Points_on_Decisions_Under_Risk

Ordóñez, L. D. - Connolly, T. - Coughlan, R. (2000): Multiple Reference Points in Satisfaction and Fairness Assessment. Journal of Behavioral Decision Making, 13, 3, 329-344. https://bit. ly/2mjvHsV

Solnick, S. J. - Hemenway, D. (1998): Is More Always Better?: A Survey on Positional Concerns. Journal of Economic Behavior \& Organization, 37, 3, 373-383. DOI: 10.1016/S01672681(98)00089-4

Veblen, T. (1899, 1979): The Theory of the Leisure Class. Harmondsworth: Penguin Books, https:// pdfs.semanticscholar.org/83d1/61647b86267cc3c02eea55725004b102854b.pdf 